\title{
UPAYA MENINGKATKAN HASIL BELAJAR MATEMATIKA MELALUI PEMBELAJARAN KOOPERATIF DENGAN PENDEKATAN STRUKTUR SISWA KELAS V SDN 3 SINGOTRUNAN KEC BANYUWANGI KAB. BANYUWANGI TAHUN AJARAN 2016-2017 \\ Dahlia Murwaningsih \\ SDN 3 Singotrunan \\ E-mail: dahliasdn3singotrunan@gmail.com
}

\begin{abstract}
Abstrak: Dalam pembelajaran matematika sangat diperlukan strategi pembelajaran yang tepat yang dapat melibatkan siswa seoptimal mungkin baik secara intelektual maupun emosional. Selain menguasai materi seorang guru juga dituntut untuk menguasai strategi-strategi penyampaian materi tersebut, cara guru menciptakan suasana kelas akan berpengaruh terhadap respon siswa dalam proses pembelajaran. Model pembelajaran kooperatif adalah salah satu model pembelajaran yang dapat meningkatkan aktifitas siswa, meningkatkan interaksi, meningkatkan penguasaan siswa terhadap materi pembelajaran dan akan meningkatkan motivasi siswa untuk aktif dalam proses pembelajaran. Salah satu pendekatan dari model pembelajaraan kooperatif adalah pendekatan struktural, pada pendekatan ini memberikan pemecahan pada penggunaan struktur yang dirancang untuk mempengaruhi pola interaksi siswa. Diharapkan siswa bekerja sama dan saling membantu dalam kelompok kecil dan lebih pada penghargaan kooperatif dan penghargaan individu. Penelitian tindakan ini dilakukan dalam 3 siklus. Dari hasil tindakan yang dilakukan terbukti dapat meningkatkan prestasi belajar siswa dengan mencapai standar ideal. Dari 55,56\% pada Siklus 1, dapat meningkat pada siklus 2 menjadi 68,89\% dan siklus 3 mencapai 85,55\%, dan secara klasikal telah mencapai ketuntasan. Hasil penelitian tindakan ini menunjukkan bahwa penerapan pembelajaran kooperatif dengan pendekatan struktur dapat meningkatkan hasil belajar siswa kelas IV dengan ketuntasan mencapai $100 \%$, dengan demikian penerapan pembelajaran kooperatif dengan pendekatan struktur efektif dalam meningkatkan hasil belajar siswa pelajaran matematika di SDN 3 Singotrunan Kecamatan Banyuwangi Kabupaten Banyuwangi.
\end{abstract}

Kata kunci: Hasil Belajar, Pembelajaran Matematika di SD, Pembelajaran Kooperatif dengan Pendekatan Struktur

\begin{abstract}
In mathematics learning, it is necessary to have the right learning strategies that can involve students as optimally as possible both intellectually and emotionally. In addition to mastering the material a teacher is also required to master the material delivery strategies, the way the teacher creates a classroom atmosphere will affect the students' response in the learning process. Cooperative learning model is one of the learning models that can increase student activity, increase interaction, increase students 'mastery of learning material and will increase students' motivation to be active in the learning process. One approach of the cooperative learning model is the structural approach, this approach provides solutions to the use of structures designed to influence student interaction patterns. Students are expected to work together and help each other in small groups and more on cooperative rewards and individual rewards. This action research was carried out in 3 cycles. From the results of the actions taken it is proven that it can improve student learning achievement by achieving ideal standards. From $55.56 \%$ in Cycle I, it can increase in cycle 2 to $68.89 \%$ and cycle 3 to reach $85.55 \%$, and classically it has reached completeness. The results of this action research indicate that the application of cooperative learning with a structural approach can improve the learning outcomes of fourth grade students
\end{abstract}




\section{ELSE (Elementary School Education Journal) \\ Volume 2 Nomor 2 Agustus 2018 \\ P-ISSN: 2581-1800 E-ISSN: 2597-4122 \\ Email: else@um-surabaya.ac.id}

with completeness reaching $100 \%$, thus the application of cooperative learning with an effective structural approach in improving learning outcomes of mathematics students at SDN 3 Singotrunan, Banyuwangi District, Banyuwangi District.

Keywords: Learning Outcomes, Mathematics Learning in Elementary Schools, Cooperative Learning with Structural Approaches

\section{PENDAHULUAN}

Matematika sangat besar pengaruhnya untuk penguasaan ilmu pengetahuan dan teknologi. Selain itu matematika juga berperan penting dalam usaha menciptakan manusia yang berkualitas sehingga pembelajaran matematika perlu mendapat perhatian besar dalam dunia pendidikan di segala jenjang pendidikan mulai dari SD sampai di tingkat SMA.

Matematika yang merupakan bagian dari MIPA, lebih menekankan pada kegiatan belajar mengajar, mengembangkan konsep dan keterampilan proses siswa dengan berbagai metode mengajar yang sesuai dengan bahan kajian yang diajarkan (Anonimus, 1995). Dalam pembelajaran matematika, sangat diperlukan strategi pembelajaran yang tepat yang dapat melibatkan siswa seoptimal mungkin baik secara intelektual maupun emosional. Karena pengajaran matematika menekankan pada keterampilan proses kelas dipengaruhi oleh beberapa faktor antara lain adalah guru dan siswa. Selain menguasai materi seorang guru juga dituntut untuk menguasai strategi-strategi penyampaian materi tersebut, cara guru menciptakan suasana kelas akan berpengaruh terhadap respon siswa dalam proses pembelajaran.Apabila guru berhasil menciptakan suasana yang menyenangkan sehingga siswa termotivasi ikut aktif dalam belajar akan memungkinkan terjadi peningkatan hasil belajar.

Guru di SDN 3 Singotrunan Banyuwangi tidak puas dalam melaksanakan proses pembelajaran. Dari hasil ulangan semester diperoleh nilai rata-rata ketruntasan hanya mencapai 3 siswa (16\%) dari 18 siswa yang telah mencapai (KKM). Hambatan yang ditemui antara lain adalah kelas selalu pasif, motivasi siswa untuk belajar sangat rendah dan sangat sulit untuk menimbulkan interaksi baik antara siswa dengan siswa antar kelompok maupun antara siswa dengan guru, sehingga kelas selalu didominasi oleh guru. Berdasarkan kenyataan yang ada maka peneliti selaku guru di SDN 3 Singotrunan. mengadakan Penelitian Tindakan Kelas untuk memperbaiki strategi pembelajaran yang dapat meningkatkan motivasi dan aktifitas siswa akan meningkat sehingga meningkatkan 
prestasi matematika kelas V SDN 3 Singotrunan Banyuwangi. Salah satu model pembelajaran yang diharapkan dapat meningkatkan motivasi dan aktivitas belajar siswa adalah melalui pembelajaran kooperatif. dengan pendekatan struktur

Model Pembelajaran Kooperatif adalah salah satu model pembelajaran yang dapat meningkatkan aktifitas siswa, meningkatkan interaksi, Individu, kelompok meningkatkan penguasaan terhadap materi sehingga menngkatkan prestasi siswa dalam pelajaran Matematika. Salah satu pendekatan dari model pembelajaraan kooperatif adalah pendekatan struktural yang dirancang untuk mempengaruhi pola interaksi siswa. Dengan pendekatan tersebut diharapkan siswa bekerja sama saling membantu dalam kelompok kecil dan besar.

Pendekatan struktural dikembangkan oleh Spencer Kagen (Kagen, 1993) yang terdiri dari dua macam struktur yang terkenal yaitu Think-Pair Share (TPS). Menurut Ibrahim (2000) TPS memiliki prosedur yang ditetapkan secara eksplisit untuk memberi siswa waktu yang lebih banyak untuk berpikir, menjawab dan saling memberikan satu sama lain. TPS adalah sebagai ganti Tanya-jawab seluruh kelas dalam pelaksanaan di kelas TPS terdiri dari langkah-langkah sebagai berikut:

1. Thinking. Guru mengajukan pertanyaan yang berhubungan dengan pelajaran, kemudian siswa diminta untuk memikirkan pertanyaan tersebut secara mandiri dalam beberapa saat.

2. Pairing. Guru meminta siswa berpasangan dengan siswa yang lain untuk mendiskusikan apa yang telah diperkirakannya, disini pasangan akan memberikan berbagai jawaban dan berbagai ide jika persoalan khusus telah diidentifikasi.

3. Sharing. Guru meminta kepada pasangan untuk berbagi dengan seluruh kelas tentang hal yang telah mereka bicarakan, dilakukan bergiliran pasangan demi pasangan sampai lebih kurang seperempat pasangan yang ada di kelas mendapatkan kesempatan untuk melaporkannya.

Dari uraian tersebut di atas, maka penulis selaku guru matematika di SDN 3 Singotrunan Banyuwangi perlu melakukan penelitian tindakan sebagai upaya perbaikan pembelajaran dengan judul "Upaya Meningkatkan Hasil Belajar Matematika melalui Pembelajaran Kooperatif dengan Pendekatan Struktur Siswa Kelas V SDN 3 Singotrunan Tahun Pelajaran 2016-2017”. 


\section{ELSE (Elementary Schod Education Journal) \\ Volume 2 Nomor 2 Agustus 2018 \\ P-ISSN: 2581-1800 E-ISSN: 2597-4122 \\ Email: else@um-surabaya.ac.id}

\section{METODE PENELITIAN}

Subjek penelitian ini adalah siswa kelas V SDN 3 Singotrunan Banyuwangi tahun pelajaran 2016-2017. Berdasarkan hasil observasi yang penulis lakukan dikelas V hasil belajar dalam pelajaran matematika masih sangat rendah. Siswa merasa kesulitan dalam belajar sehingga siswa kurang respon terhadap pembelajaran di kelas. Penelitian ini merupakan penelitian tindakan kelas, yang dilakukan secara bertahap-tahap sampai mendapatkan hasil yang diinginkan.

Rancangan Penelitian Tindakan Kelas (PTK) menurut (Arikunto, 2007) adalah seperti gambar berikut.

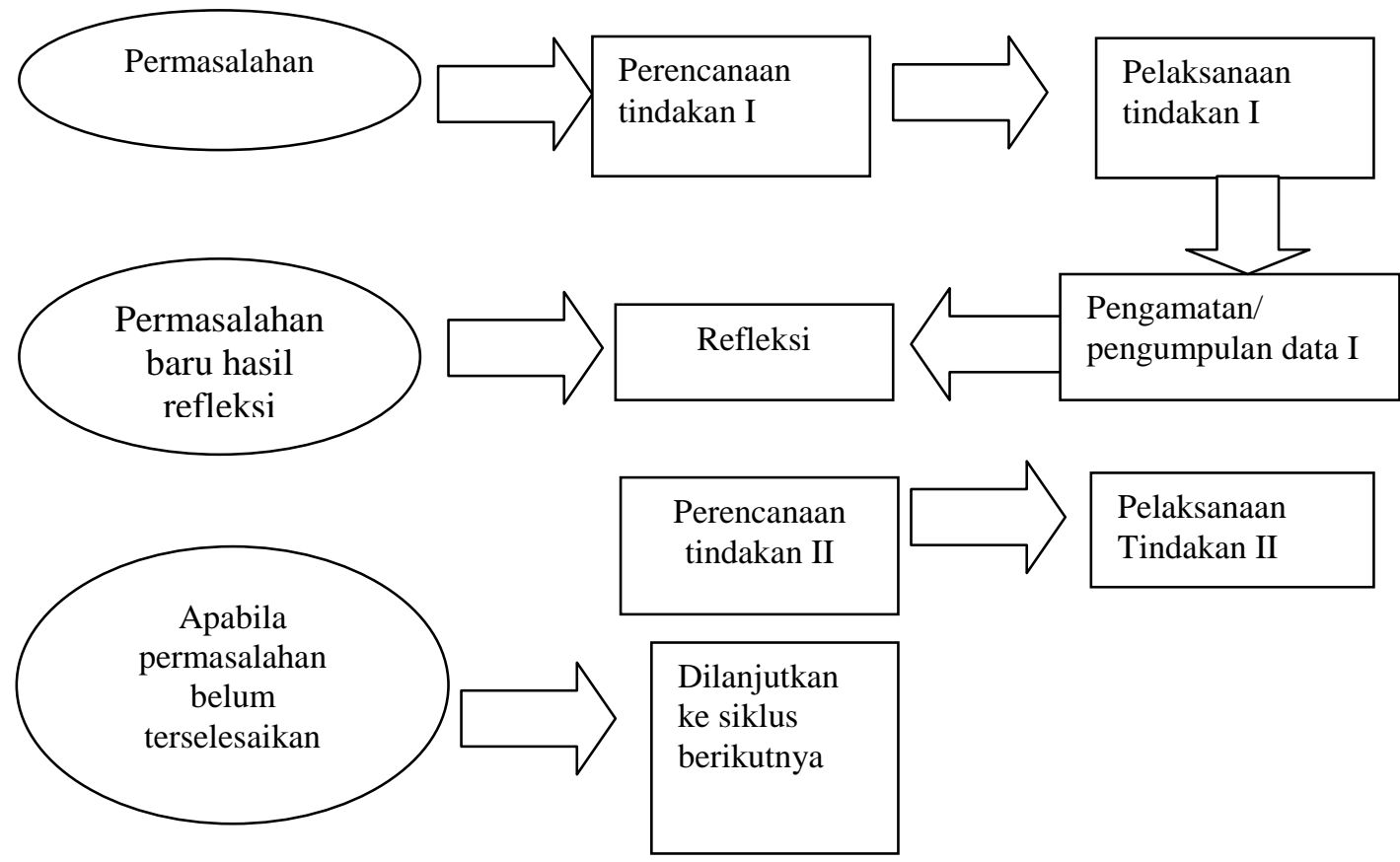

\section{Gambar 1. Alur Penelitian Tindakan Kelas}

\section{Perencanaan}

Tahapan ini berupa rancangan tindakan yang menjelaskan tentang apa, mengapa, kapan, di mana, oleh siapa, dan bagaimana tindakan tersebut dilakukan. Pada PTK di mana peneliti dan guru adalah orang yang berbeda, dalam tahap menyusun rancangan harus ada kesepakatan antara keduanya. Rancangan harus dilakukan bersama antara guru yang melakukan tindakan dengan peneliti yang mengamati proses jalannya tindakan. Hal tersebut untuk mengurangi unsur subjektivitas pengamat serta mutu kecermatan pengamatan yang dilakukan. 


\section{Tindakan}

Pada tahap ini, rancangan tindakan tersebut tentu saja sebelumnya telah dilatih kepada si pelaksana tindakan (guru) untuk dapat diterapkan di dalam kelas sesuai dengan skenarionya. Skenario dari tindakan harus dilaksanakan dengan baik dan tampak wajar.

\section{Pengamatan atau observasi}

Tahap ini sebenarnya berjalan bersamaan dengan saat pelaksanaan. Pengamatan dilakukan pada waktu tindakan sedang berjalan, jadi, keduanya berlangsung dalam waktu yang sama. Pada tahap ini peneliti (atau guru apabila ia bertindak sebagai peneliti) melakukan pengamatan dan mencatat semua hal yang diperlukan dan terjadi selama pelaksanaan tindakan berlangsung. Pengumpulan data ini dilakukan dengan menggunakan format observasi / penilaian yang telah tersusun, termasuk juga pengamatan secara cermat pelaksanaan skenario tindakan dari waktu ke waktu serta dampaknya terhadap proses dan hasil belajar siswa.

\section{Refleksi}

Tahapan ini dimaksudkan untuk mengkaji secara menyeluruh tindakan yang telah dilakukan, berdasarkan data yang telah terkumpul, kemudian dilakukan evaluasi guna menyempurnakan tindakan berikutnya. Refleksi dalam PTK mencakup analisis, sintesis, dan penilaian terhadap hasil pengamatan atas tindakan yang dilakukan. Jika terdapat masalah dari proses refleksi maka dilakukan proses pengkajian ulang melalui siklus berikutnya yang meliputi kegiatan perencanaan ulang, tindakan ulang, dan pengamatan ulang sehingga permasalahan dapat teratasi.

\section{HASIL DAN PEMBAHASAN}

Subjek penelitian ini adalah siswa kelas V SDN 3 Singotrunan. Banyuwangi tahun pelajaran 2016- 2017 berjumlah 18 siswa. Penelitian tindakan kelas dilaksanakan sesuai dengan prosedur rencana pembelajaran dan skenario pembelajaran. Berikut di sajikan data persiklus. 


\section{Siklus I}

Adapun proses belajar mengajar mengacu pada rencana pelajaran yang telah dipersiapkan. Pengamatan (observasi) dilaksanakan bersamaan dengan pelaksaaan belajar mengajar. Pada akhir proses belajar mengajar siswa diberi tes formatif I dengan tujuan untuk mengetahui tingkat keberhasilan siswa dalam proses belajar mengajar yang telah dilakukan. Adapun data hasil penelitian pada siklus I. adalah seperti pada tabel berikut.

Tabel 1. Daftar Nilai Tes Pelajaran Matematika Melalui Penerapan Pembelajaran Kooperatif dengan Pendekatan Struktur pada Siklus I

\begin{tabular}{|c|c|c|c|c|}
\hline \multirow{2}{*}{ No } & \multirow{2}{*}{ Nama } & \multirow{2}{*}{ Skor } & \multicolumn{2}{|c|}{ Keterangan } \\
\hline & & & Tuntas & Tidak Tuntas \\
\hline 1 & Kholifatur Afanda & 50 & & $\sqrt{ }$ \\
\hline 2 & RiskiyaniSholikah & 50 & & $\sqrt{ }$ \\
\hline 3 & Evitasari & 70 & $\sqrt{ }$ & \\
\hline 4 & Wisnu Nugroho & 50 & & $\sqrt{ }$ \\
\hline 5 & Adi Saputra & 50 & & $\sqrt{ }$ \\
\hline 6 & Bagas Saputra & 50 & & $\sqrt{ }$ \\
\hline 7 & Bagus Saputra & 50 & & $\sqrt{ }$ \\
\hline 8 & Edy Firdaus & 50 & & $\sqrt{ }$ \\
\hline 9 & Dwi Lestari & 70 & $\sqrt{ }$ & \\
\hline 10 & Muhamad Yusuf & 60 & & $\sqrt{ }$ \\
\hline 11 & Ahmad Mubarok & 60 & & $\sqrt{ }$ \\
\hline 12 & Yogi Apriyanti & 50 & & $\sqrt{ }$ \\
\hline 13 & Reva Wulandari & 50 & & $\sqrt{ }$ \\
\hline 14 & Sahrul Ramadhani & 50 & & $\sqrt{ }$ \\
\hline 15 & Dian Kumalasari & 70 & $\sqrt{ }$ & \\
\hline 16 & Ainun Nisfi & 60 & & $\sqrt{ }$ \\
\hline 17 & Brima Nada & 60 & & $\sqrt{ }$ \\
\hline 18 & Nur Indahsari & 50 & & $\sqrt{ }$ \\
\hline \multicolumn{2}{|c|}{ Jumlah Total } & 1000 & & \\
\hline \multicolumn{2}{|c|}{ Rata- rata kelas } & 55,56 & & \\
\hline \multicolumn{2}{|c|}{ Skor Maksimum Individu } & 100 & & \\
\hline \multicolumn{2}{|c|}{ Skor Maksimum Kelas } & 1800 & & \\
\hline \multicolumn{2}{|c|}{ Tuntas / Tidak Tuntas v } & $3 / 15$ & 3 & 15 \\
\hline \multicolumn{2}{|c|}{ Prosentase } & & $16,1 \%$ & $83,9 \%$ \\
\hline
\end{tabular}

Dari tabel di atas dapat dijelaskan bahwa penerapan pembelajaran kooperatif dengan pendekatan struktur diperoleh nilai rata-rata prestasi belajar siswa adalah 55,56\% atau ada 3 siswa dari 18 siswa sudah tuntas belajar. Hasil tersebut menunjukkan bahwa pada siklus pertama secara klasikal siswa belum tuntas belajar, karena siswa yang memperoleh nilai $\geq 65$ hanya sebesar $16,1 \%$, lebih kecil dari persentase ketuntasan yang dikehendaki yaitu sebesar $85 \%$. Hal ini disebabkan karena siswa masih merasa baru dan belum mengerti apa yang dimaksudkan dan digunakan guru dengan menerapkan pembelajaran kooperatif dengan pendekatan struktur. 
Siklus II

Dalam hal ini peneliti bertindak sebagai guru. Adapun proses belajar mengajar mengacu pada rencana pelajaran dengan memperhatikan revisi pada siklus I, sehingga kesalahan atau kekurangan pada siklus I tidak terulang lagi pada siklus II. Pengamatan (observasi) dilaksanakan bersamaan dengan pelaksanaan belajar mengajar. Pada akhir proses belajar mengajar siswa diberi tes formatif II dengan tujuan untuk mengetahui tingkat keberhasilan siswa dalam proses belajar mengajar yang telah dilakukan. Instrumen yang digunakan adalah tes formatif II. Adapun data hasil penelitian pada siklus II adalah sebagai berikut.

Tabel 2. Daftar Nilai Tes Pelajaran Matematika melalui Penerapan Pembelajaran Kooperatif dengan Pendekatan Struktur pada Siklus II

\begin{tabular}{|c|c|c|c|c|}
\hline \multirow{2}{*}{ No } & \multirow{2}{*}{ Nama } & \multirow{2}{*}{ Skor } & \multicolumn{2}{|c|}{ Keterangan } \\
\hline & & & Tuntas & Tidak Tuntas \\
\hline 1 & Kholifatur Afanda & 70 & $\sqrt{ }$ & \\
\hline 2 & RiskiyaniSholikah & 60. & & $\sqrt{ }$ \\
\hline 3 & Evitasari & 80 & $\sqrt{ }$ & \\
\hline 4 & Wisnu Nugroho & 70 & $\sqrt{ }$ & \\
\hline 5 & Adi Saputra & 70 & $\sqrt{ }$ & \\
\hline 6 & Bagas Saputra & 60 & & $\sqrt{ }$ \\
\hline 7 & Bagus Saputra & 70 & $\sqrt{ }$ & \\
\hline 8 & Edy Firdaus & 60. & & $\sqrt{ }$ \\
\hline 9 & Dwi Lestari & 80 & $\sqrt{ }$ & \\
\hline 10 & Muhamad Yusuf & 70 & $\sqrt{ }$ & \\
\hline 11 & Ahmad Mubarok & 70 & $\sqrt{ }$ & \\
\hline 12 & Yogi Apriyanti & 60 & & $\sqrt{ }$ \\
\hline 13 & Reva Wulandari & 70 & $\sqrt{ }$ & \\
\hline 14 & Sahrul Ramadhani & 60. & & $\sqrt{ }$ \\
\hline 15 & Dian Kumalasari & 80 & $\sqrt{ }$ & \\
\hline 16 & Ainun Nisfi & 70 & $\sqrt{ }$ & \\
\hline 17 & Brima Nada & 60. & & $\sqrt{ }$ \\
\hline 18 & Nur Indahsari & 80 & $\sqrt{ }$ & \\
\hline \multicolumn{2}{|c|}{ Jumlah Total } & 1240 & & \\
\hline \multicolumn{2}{|c|}{ Rata - rata kelas } & 68,89 & & \\
\hline \multicolumn{2}{|c|}{ Skor Maksimum Individu } & 100 & & \\
\hline \multicolumn{2}{|c|}{ Skor Maksimum Kelas } & 1800 & & \\
\hline \multicolumn{2}{|c|}{ Tuntas / Tidak Tuntas } & & 12 & 6 \\
\hline \multicolumn{3}{|c|}{ Prosentase } & $64,4 \%$ & $35,6 \%$ \\
\hline
\end{tabular}

Dari tabel di atas diperoleh nilai rata-rata prestasi belajar siswa adalah 68,89\% dan ketuntasan belajar mencapai 64,4\% atau ada 12 siswa dari 18 siswa sudah tuntas belajar. Hasil ini menunjukkan bahwa pada siklus II ini ketuntasan belajar secara klasikal telah mengalami peningkatan cukup lebih baik dari siklus I. Adanya peningkatan hasil belajar siswa ini karena setelah guru menginformasikan bahwa setiap akhir pelajaran akan selalu 


\section{ELSE (Elementary School Education Journal) \\ Volume 2 Nomor 2 Agustus 2018 \\ P-ISSN: 2581-1800 E-ISSN: 2597-4122 \\ Email: else@um-surabaya.ac.id}

diadakan tes sehingga pada pertemuan berikutnya siswa lebih termotivasi untuk belajar.

Selain itu siswa juga sudah mulai mengerti apa yang dimaksudkan dan dinginkan guru dalam menerapkan pembelajaran kooperatif dengan pendekatan struktur.

\section{Siklus III}

Dalam hal ini peneliti bertindak sebagai guru. Adapun proses belajar mengajar mengacu pada rencana pelajaran dengan memperhatikan revisi pada siklus II, sehingga kesalahan atau kekurangan pada siklus II tidak terulang lagi pada siklus III. Pengamatan (observasi) dilaksanakan bersamaan dengan pelaksanaan belajar mengajar. Pada akhir proses belajar mengajar siswa diberi tes formatif III dengan tujuan untuk mengetahui tingkat keberhasilan siswa dalam proses belajar mengajar yang telah dilakukan. Instrumen yang digunakan adalah tes formatif III. Adapun data hasil penelitian pada siklus III adalah sebagai berikut.

Tabel 3. Daftar Nilai Tes Pelajaran Matematika melalui Penerapan Pembelajaran

Kooperatif dengan Pendekatan Struktur pada Siklus III

\begin{tabular}{|c|c|c|c|c|}
\hline \multirow{2}{*}{ No } & \multirow{2}{*}{ Nama } & \multirow{2}{*}{ Skor } & \multicolumn{2}{|c|}{ Keterangan } \\
\hline & & & Tuntas & Tidak Tuntas \\
\hline 1 & Kholifatur Afanda & 90 & $\sqrt{ }$ & \\
\hline 2 & RiskiyaniSholikah & 80 & $\sqrt{ }$ & \\
\hline 3 & Evitasari & 90 & $\sqrt{ }$ & \\
\hline 4 & Wisnu Nugroho & 80 & $\sqrt{ }$ & \\
\hline 5 & Adi Saputra & 90 & $\sqrt{ }$ & \\
\hline 6 & Bagas Saputra & 80 & $\sqrt{ }$ & \\
\hline 7 & Bagus Saputra & 90 & $\sqrt{ }$ & \\
\hline 8 & Edy Firdaus & 80 & $\sqrt{ }$ & \\
\hline 9 & Dwi Lestari & 90 & $\sqrt{ }$ & \\
\hline 10 & Muhamad Yusuf & 80 & $\sqrt{ }$ & \\
\hline 11 & Ahmad Mubarok & 90 & $\sqrt{ }$ & \\
\hline 12 & Yogi Apriyanti & 80 & $\sqrt{ }$ & \\
\hline 13 & Reva Wulandari & 90 & $\sqrt{ }$ & \\
\hline 14 & Sahrul Ramadhani & 80 & $\sqrt{ }$ & \\
\hline 15 & Dian Kumalasari & 90 & $\sqrt{ }$ & \\
\hline 16 & Ainun Nisfi & 90 & $\sqrt{ }$ & \\
\hline 17 & Brima Nada & 80 & $\sqrt{ }$ & \\
\hline 18 & Nur Indahsari & 90 & $\sqrt{ }$ & \\
\hline \multicolumn{2}{|c|}{ Jumlah Total } & 1540 & & \\
\hline \multicolumn{2}{|c|}{ Rata- rata kelas } & 85,55 & & \\
\hline \multicolumn{2}{|c|}{ Skor Maksimum Individu } & 100 & & \\
\hline \multicolumn{2}{|c|}{ Skor Maksimum Kelas } & 1800 & & \\
\hline \multicolumn{2}{|c|}{ Tuntas V Tidak Tuntas } & & 18 & $\mathbf{0}$ \\
\hline \multicolumn{2}{|c|}{ Prosentase } & & $100 \%$ & $0 \%$ \\
\hline
\end{tabular}


Berdasarkan tabel di atas diperoleh nilai rata-rata tes formatif sebesar $85,55 \%$ dari 18 siswa telah tuntas secara keseluruhan. Maka secara klasikal ketuntasan belajar yang telah tercapai sebesar $100 \%$. Hasil pada siklus III ini mengalami peningkatan lebih baik dari siklus II. Adanya peningkatan hasil belajar pada siklus III ini dipengaruhi oleh adanya peningkatan kemampuan guru dalam menerapkan pembelajaran kooperatif dengan pendekatan struktur, sehingga siswa menjadi lebih terbiasa dengan pembelajaran seperti ini sehingga siswa lebih mudah dalam memahami materi yang telah diberikan. Di samping itu ketuntasan ini juga dipengaruhi oleh kerja sama dari siswa yang telah menguasai materi pelajaran untuk mengajari temannya yang belum menguasai sebagai tutor sebaya.

Tabel 4. Analisis Hasil Tes Pelajaran Matematika melalui Penerapan Pembelajaran Kooperatif dengan Pendekatan Struktur Sebelum dan Sesudah Diberi Tindakan

\begin{tabular}{|c|c|c|c|c|}
\hline No & Nama & $\begin{array}{c}\text { Skor sebelum } \\
\text { Tindakan } \\
\text { Siklus } 1\end{array}$ & $\begin{array}{c}\text { Skor setelah } \\
\text { Tindakan } 1 \\
\text { Siklus } 2\end{array}$ & $\begin{array}{c}\text { Skor setelah } \\
\text { Tindakan } 2 \\
\text { Siklus } 3\end{array}$ \\
\hline 1 & Kholifatur Afanda & 50 & 70 & 90 \\
\hline 2 & RiskiyaniSholikah & 50 & 60. & 80 \\
\hline 3 & Evitasari & 70 & 80 & 90 \\
\hline 4 & Wisnu Nugroho & 50 & 70 & 80 \\
\hline 5 & Adi Saputra & 50 & 70 & 90 \\
\hline 6 & Bagas Saputra & 50 & 60 & 80 \\
\hline 7 & Bagus Saputra & 50 & 70 & 90 \\
\hline 8 & Edy Firdaus & 50 & 60. & 80 \\
\hline 9 & Dwi Lestari & 70 & 80 & 90 \\
\hline 10 & Muhamad Yusuf & 60 & 70 & 80 \\
\hline 11 & Ahmad Mubarok & 60 & 70 & 90 \\
\hline 12 & Yogi Apriyanti & 50 & 60 & 80 \\
\hline 13 & Reva Wulandari & 50 & 70 & 90 \\
\hline 14 & Sahrul Ramadhani & 50 & 60. & 80 \\
\hline 15 & Dian Kumalasari & 70 & 80 & 90 \\
\hline 16 & Ainun Nisfi & 60 & 70 & 90 \\
\hline 17 & Brima Nada & 60 & 60. & 80 \\
\hline 18 & Nur Indahsari & 50 & 80 & 90 \\
\hline \multicolumn{2}{|c|}{ Jumlah Total } & 1000 & 1240 & 1540 \\
\hline \multicolumn{2}{|c|}{ Rata- rata kelas } & 55,56 & 68,89 & 85,55 \\
\hline \multicolumn{2}{|c|}{ Skor Maksimum Individu } & 100 & 100 & 100 \\
\hline \multicolumn{2}{|c|}{ Skor Maksimum Kelas } & 1800 & 1800 & 1800 \\
\hline
\end{tabular}




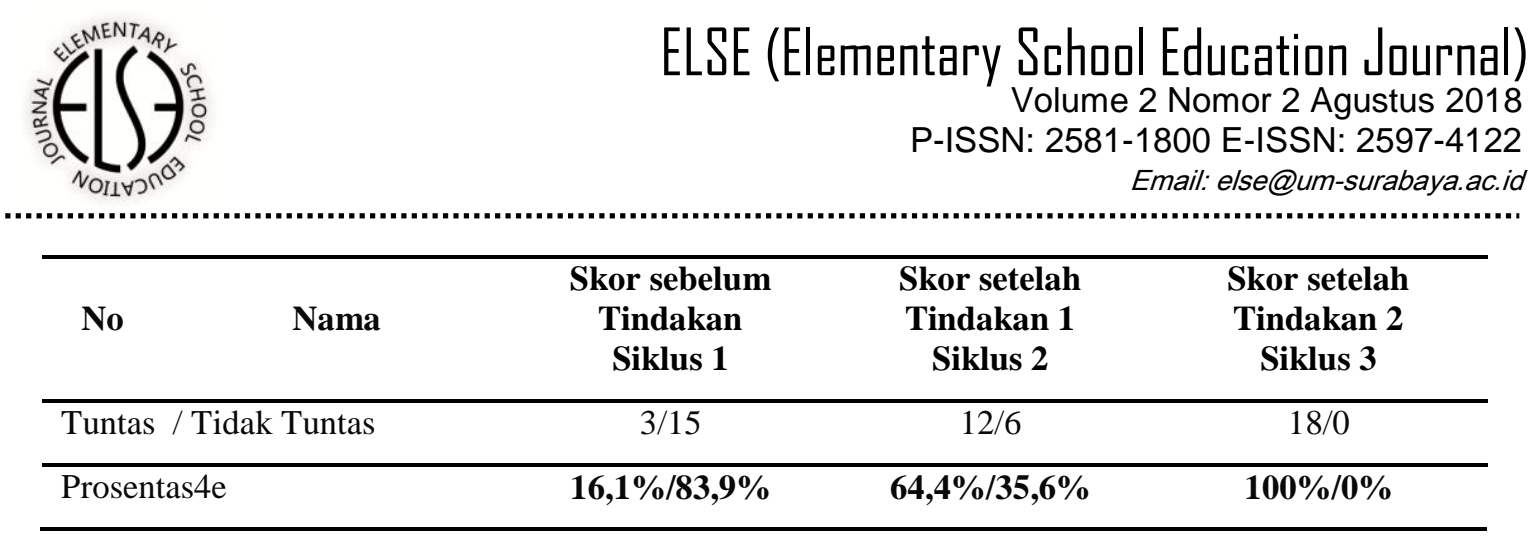

\section{Pembahasan Hasil Penelitian}

1. Ketuntasan Hasil belajar Siswa

Berdasarkan hasil penelitian ini menunjukkan bahwa penerapan pembelajaran kooperatif dengan pendekatan struktur berdampak positif dalam meningkatkan prestasi belajar siswa. Hal ini dapat dilihat dari semakin mantapnya pemahaman siswa terhadap materi yang disampaikan guru (ketuntasan belajar meningkat dari siklus I, II, III) yaitu 55,56\%, 68.89\%, 85,55\%. Pada siklus III ketuntasan belajar siswa secara klasikal telah tercapai.

2. Kemampuan Guru dalam Mengelola Pembelajaran

Berdasarkan analisis data, diperoleh aktivitas siswa dalam proses pembelajaran kooperatif dengan pendekatan struktur dalam setiap siklus mengalami peningkatan. Hal ini berdampak positif terhadap prestasi belajar siswa yaitu dapat ditunjukkan dengan meningkatnya nilai rata-rata siswa pada setiap siklus yang terus mengalami peningkatan.

3. Aktivitas Guru dan Siswa Dalam Pembelajaran

Berdasarkan analisis data, diperoleh aktivitas siswa dalam proses pembelajaran kooperatif dengan pendekatan struktur adalah siswa dapat mengerjakan soal matematika dengan alat peraga yang tertsedia, memperhatikan penjelasan guru, dan diskusi antar siswa saling lempar pertanyaan saling menjawab dengan benar /antara siswa dengan guru. Jadi aktivitas siswa dapat dikategorikan aktif.

Aktivitas guru selama pembelajaran telah melaksanakan langkah-langkah pembelajaran kooperatif dengan pendekatan struktur dengan baik. Hal ini terlihat dari aktivitas guru membimbing dan mengamati siswa dalam mengerjakan soal pelajaran, menjelaskan,dengan senang memberi umpan balik berupa pertanyaan yang merangsanmg siswasengan belajar matematika evaluasi/tanya jawab di mana prosentase untuk aktivitas di atas cukup besar. 


\section{ELSE (Elementary School Education Journal) \\ Volume 2 Nomor 2 Agustus 2018 \\ P-ISSN: 2581-1800 E-ISSN: 2597-4122 \\ Email: else@um-surabaya.ac.id}

\section{KESIMPULAN DAN SARAN}

Dari hasil kegiatan pembelajaran yang telah dilakukan selama tiga siklus, berdasarkan analisis dan pembahasan yang telah dilakukan dapat disimpulkan sebagai berikut.

1. Pembelajaran kooperatif dengan pendekatan struktur memiliki dampak positif dalam meningkatkan prestasi belajar siswa di SDN 3 Singotrunan Banyuwangi yang ditandai dengan peningkatan ketuntasan belajar siswa dalam setiap siklus, yaitu 55,56\% (siklus I), 68,89\% (siklus II), $85,55 \%$ (siklus III).

2. Penerapan pembelajaran kooperatif dengan pendekatan struktur pada pelajaran matematika berpengaruh positif, yaitu dapat meningkatkan prestasi belajar siswa.

3. Penerapan pembelajaran kooperatif dengan pendekatan struktur efektif untuk meningkatkan prestasi siswa dan mengingat kembali materi ajar yang telah diterima siswa selama ini, sehingga mereka merasa siap untuk menghadapi pelajaran berikutnya.

\section{DAFTAR PUSTAKA}

Arikunto, Suharsimi. 2002. Prosedur Penelitian Suatu Pendekatan Praktek. Jakarta: Rineksa Cipta.

.2007. Penelitian Tindakan Kelas. Bandung: remaja Rosdkaraya.

Depdiknas RI,2004.Undang Undang No 20 tentang sistem pendidikan nasional SISDIKNAS ) Jakarta: Depdiknas.

. 2006. Kurikulum 2006. Jakarta: Depdiknas.

Dahar, Ratna Wilis. 1988. Teori-teori Belajar. Jakarta: Dirjen Dikti P2LPTK Depdikbud.

Dimyati dan Mudjiono. 2002. Belajar dan pembelajaran. Jakarta: Rineka Cipta.

Djamarah dan Zein, (1994). Dasar-Dasar Evaluasi Pendidikan. Bumi Aksara, Jakarta.

Djamarah, Syaiful Bahri dkk. 2002. Strategi Belajar Mengajar. Jakarta: Rineka Cipta.

Muhammad, Nur dkk,1999.Teori Belajar. Surabaya: Unesa University Press.

Muslimin, I. 2000. Pembelajaran Kooperatif. Unesa. Surabaya.

Suyatno.2009. Menjelajah pembelajaran Inovatif. Sidoarjo: Masmedia Buana Pustaka. 


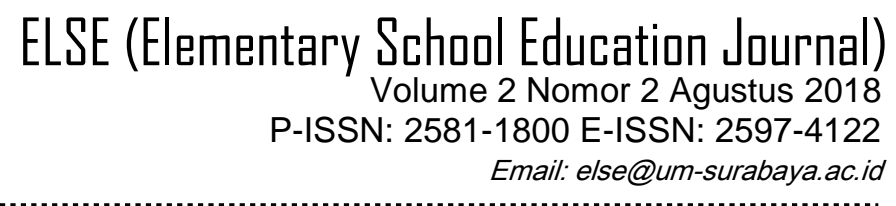

Nasution S., 2001. Berbagai Pendekatan Dalam Proses Belajar Mengajar. Bina Aksara. Jakarta.

Sudjana, Nana. 1989. Dasar-dasar Proses Belajar Mengajar. Bandung: Sinar Baru.

Nurkancana, W. 1983. Evaluasi Pendidikan. Penerbit Usaha Nasional. Surabaya.

Purwanto. 1991. Prinsip-prinsip dan Teknik Evaluasi Mengakar. Rosda Karya. Bandung.

Sudhana. 1987. Cara Belajar Siswa Aktif dalam Proses Belajar Mengajar. Sinar Baru Algesindo. Jakarta.

Suhermi. 2000. Model Pembelajaran Kooperatif. Departemen Pendidikan Nasional UNRI. Pekanbaru.

Slavin, R.E. 1995. Cooperative Learning; Theori Research and Practice. Allyn Bacon. Boston. 